\title{
SURVIVING SEXUAL ABUSE IN EVERYDAY LIFE: FORMS OF RESISTANCE USED BY CHILDREN AND ADOLESCENTS ${ }^{1}$
}

\author{
Margaret Olinda de Souza Carvalho e Lira², Rosane Gonçalves Nitschke ${ }^{3}$, Adriana Diniz Rodrigues 4 \\ Vanda Palmarella Rodrigues ${ }^{5}$, Telmara Menezes Couto ${ }^{6}$, Normélia Maria Freire Diniz ${ }^{7}$
}

${ }^{1}$ Article extracted from dissertation - Quotidiano de mulheres do semiárido nordestino que sofreram abuso sexual no contexto familiar, presented Programa de Pós-Graduação em Enfermagem, Escola de Enfermagem, Universidade Federal da Bahia (UFBA). Scholarship Fundação de Amparo à Pesquisa do Estado da Bahia (FAPESB), in 2015.

2 Ph.D. in Nursing, Professor, Nursing Collegiate, Universidade Federal do Vale do São Francisco. Petrolina, Pernambuco, Brazil. E-mail: olindalira@gmail.com

${ }^{3}$ Ph.D. in Nursing. Professor, Departamento de Enfermagem in the Universidade Federal de Santa Catarina. Florianópolis, Santa Catarina, Brazil. E-mail: rosanenitschke@gmail.com

${ }^{4}$ Ph.D. in Nursing. Professor, Undergraduate Nursing Degree Course in the Faculdade Regional da Bahia. Alagoinhas, Bahia, Brasil. E-mail: adrianadinizr@gmail.com

${ }^{5}$ Ph.D. in Nursing. Professor, Undergraduate Nursing Course, Universidade Estadual do Sudoeste da Bahia. Vitória da Conquista, Bahia, Brazil. E-mail: vprodrigues@uesb.edu.br

${ }^{6}$ Ph.D. in Nursing. Professor, Escola de Enfermagem, UFBA. Salvador, Bahia, Brazil. E-mail: telmaracouto@gmail.com

7 Ph.D. in Nursing. Professor, Escola de Enfermagem, UFBA. Salvador, Bahia, Brazil. E-mail: normeliadiniz@gmail.com

\begin{abstract}
Objective: to understand the forms of resistance used by children and adolescent victims of sexual abuse in the everyday family routine. Method: qualitative research developed at an Assistance Center to Women in Situations of Violence in the semi-arid region of Pernambuco, with data collected between June and November of 2014 through interviews with nine women. The analysis process was based on notions of Comprehensive Sociology and Everyday Life, with data organized by affinity, interpreted and categorized.

Results: the emerged categories: ritualization of sexual abuse of children and adolescents in the family routine: acceptance of destiny through passivity; Camouflage to survive the experience of sexual abuse: silence, astuteness and acting/pretending in order to escape abuse, Between hidden sexual abuse and The revelation of sexual abuse. It can be seen that episodes of abuse occurred in secret and under the threat of abusers through intimidating gestures or words. Victims did not confront them or call attention or ask for help, they used tricks like metaphors, laughs and ironic words, as well as ridiculing them with excuses, hiding, pretending to be asleep or fleeing to the street.

Conclusion: the underground centrality present in sexual abuse triggered forms of resistance in opposition to the oppression generated by the abuser in which, in accepting that way of life, the participants developed different survival mechanisms, as well as participating in voluntary work, music and sports, these vents alleviate the burden of concealing the abuse.

DESCRIPTORS: Survival. Childhood sexual abuse. Violence against women. Child. Adolescent. Family relationships. Daily activities.

\section{SOBREVIVENDO AO ABUSO SEXUAL NO COTIDIANO FAMILIAR: FORMAS DE RESISTÊNCIA UTILIZADAS POR CRIANÇAS E ADOLESCENTES}

\begin{abstract}
RESUMO
Objetivo: apreender formas de resistência utilizadas por crianças e adolescentes em um cotidiano familiar de abuso sexual.

Método: pesquisa qualitativa desenvolvida em um Centro de Atendimento à Mulher em Situação de Violência no semiárido de Pernambuco, com dados coletados entre junho e novembro de 2014 por meio de entrevista com nove mulheres. O processo de análise fundamentou-se em noções da Sociologia Compreensiva e do Cotidiano, com dados organizados por afinidade, interpretados e categorizados.

Resultados: emergiram as categorias: ritualização do abuso sexual de crianças e adolescentes no cotidiano familiar: aceitação da vida pela passividade; camuflagens para sobreviver ao vivido de abuso sexual: silêncio, astúcia e duplo jogo; e, entre o oculto e a revelação do abuso sexual. Pode-se perceber que os episódios de abuso ocorriam em segredo e sob a ameaça dos abusadores através de gestos ou palavras intimidadoras. As vítimas não entravam em confronto com eles e para chamar a atenção ou pedir auxílio usavam artimanhas como metáforas, risos e palavras irônicas, além de despistá-los com desculpas, escondendo-se, fingindo dormir ou fugindo para a rua.

Conclusão: a centralidade subterrânea presente no abuso sexual desencadeou formas de resistência em oposição à opressão gerada pelo abusador em que, para aceitação da vida, as participantes desenvolveram diferentes mecanismos de sobrevivência, além de encontrar no trabalho voluntário, música e esporte, os respiradouros para aliviar o peso gerado pela ocultação do abuso.
\end{abstract}

DESCRITORES: Sobrevivência. Abuso sexual na infância. Violência contra a mulher. Criança. Adolescente. Relações familiares. Atividades cotidianas. 


\title{
SOBREVIVIENDO AL ABUSO SEXUAL EN EL COTIDIANO FAMILIAR: FORMAS DE RESISTENCIA UTILIZADAS POR NIÑOS Y ADOLESCENTES
}

\begin{abstract}
RESUMEN
Objetivo: aprender formas de resistencia utilizadas por niños y adolescentes en un cotidiano familiar de abuso sexual.

Método: investigación cualitativa desarrollada en un Centro de Atendimiento a la Mujer en Situación de Violencia en el Semiárido de Pernambuco, con datos recolectados entre junio y noviembre de 2014, por medio de entrevista con nueve mujeres. El proceso de análisis se fundamentó en nociones de la Sociología Comprensiva y del Cotidiano, con datos organizados por afinidad, interpretados y categorizados.

Resultados: emergieron las categorías: ritualización del abuso sexual de niños y adolescentes en el cotidiano familiar: aceptación de la vida por la pasividad; camuflajes para sobrevivir a lo vivido sobre el abuso sexual: silencio, astucia y doble juego, y, entre lo oculto y la revelación del abuso sexual. Puede percibirse que los episodios de abuso ocurrían en secreto y bajo la amenaza de los abusadores a través de gestos o palabras intimidantes. Las víctimas no entraban en confrontación con ellos y para llamar la atención o pedir auxilio usaban artimañas como metáforas, risas y palabras irónicas, además de despistarlos con disculpas, escondiéndose, fingiendo dormir o escapándose para la calle.

Conclusión: la centralidad subterránea presente en el abuso sexual desencadenó formas de resistencia en oposición a la opresión generada por el abusador en que, para la aceptación de la vida, las participantes desarrollaron diferentes mecanismos de sobrevivencia, además de encontrar en el trabajo voluntario, música y deporte, los respiraderos para aliviar el peso generado por la ocultación del abuso.

DESCRIPTORES: Supervivencia. Abuso sexual infantil. Violencia contra la mujer. Niño. Adolescente. Relaciones familiares. Actividades cotidianas.
\end{abstract}

\section{INTRODUCTION}

Sexual abuse in the family context is the form of violence against children and adolescents which causes great indignation, considering the circumstances in which it occurs, because in addition to the physical, psychological and chronological fragilities inherent to the victims, in most cases girls are the victim of the violence, carried out by a man who takes advantage or the trust of the family, to whom they are bound to by affection, trust or dependency relationships. ${ }^{1}$

Recognized as a crime, sexual abuse in the family results from misunderstandings that propagate over generations regarding what is allowed and what is forbidden in sexuality, where children and adolescents are used for the sexual satisfaction of an adult person. ${ }^{2}$

Epidemiological data from the World Health Organization show the cases of sexual abuse against children and adolescents in all countries of the world and present a different prevalence between the sexes, namely $18 \%$ for girls and $7.6 \%$ for boys. ${ }^{3}$

The higher prevalence of female sexual abuse is rooted in patriarchy, which throughout history incorporates male-dominated social relationships that determine unequal social roles and opportunities between men and women. ${ }^{4-5}$ As we can see, male dominance accentuates the submission and perpetuation of violence against women which, in relation to girls and adolescents, the abusive situation occurs in a game of seduction, threat, blackmail and pacts that the abuser uses repeatedly, to exercise control over the victim..$^{6-7}$

This dynamic leads to a confusion of the roles of victim and abuser: in an imaginary of fear, a sexu- ally abused girl cannot react or contest the authority exercised by her abuser, and although she does not agree, she feels unable to prevent new episodes from happening. Therefore, no girl is prepared to suffer mistreatment, above all, sexual abuse. Thus, in the face of threats, victims often keep the fact secret and, and in order to alleviate the pressure from the abuser, develop strategies to survive abuse..$^{8-9}$

In these situations, there is an underground centrality that occupies the spaces of the daily life of girls and adolescents and hides this experience for a different time for each one of them. Before our eyes they give hints of their experiences, through small gestures and seemingly unimportant attitudes, which often go unnoticed, for lack of sensitivity on our part.

Situations of sexual abuse fall into the category of violence classified as banal violence and trigger forms of passive resistance, showing the subterranean centrality that emerges from the opposition to the power of the abuser, in which, without entering into confrontation, the victims are opposed by different mechanisms of survival. ${ }^{10}$

Because the experience of sexual abuse can be staged through tricks or passivity, as forms of resistance or acceptance of fate and presented as acceptance of destiny silence, astuteness, acting/ pretending and solidarity. Thus, it is possible to confront the tragedy of sexual abuse by acting or pretending to avoid the reality of the abuse, which is shown in theatricality by the use of personas, a resource that allows the person to play different roles to protect himself from the oppression generated by a phenomenon. ${ }^{10-11}$ 
Astuteness is a form of resistance that occurs when the person uses different tactics to keep away from danger. Thus, it can camouflage and manifest itself through mockery, laughter, irony or the nonverbal, in a silence that compromises the visibility of the phenomenon. ${ }^{10-11}$

As for acting/ pretending, this is a milder way to experience an experience. It is a sort of reckoning or leveling: in an attitude of passivity, there is neither refusal nor complete acceptance. ${ }^{10}$ It can be used through silence to share experiences difficult to face, which in its revealing strength, that which is not heard, listened to or answered, is indicative of "resilience." 10:125

Therefore, with sexual abuse among situations of difficult confrontation, girls and their families can use the tactics mentioned to avoid confrontation with the abuser, resist the threats that the phenomenon represents to the family balance and thus survive. It is in this context that this research has the objective of understanding the forms of resistance used by children and adolescents in a daily routine of sexual abuse.

\section{METHOD}

Qualitative research based on Comprehensive and Everyday Life Sociology, which through notions and theoretical assumptions and sensitivity, helps us to understand and designate details, contours and limits of social data, in order to know how give an account of its wealth. In this research, the method was adopted assumption and was used as an investigation resource which, with its methodological utility, allows to describe situations and representations that constitute daily life in depth. Thus, to study recurrent situations of everyday life, such as violence, we highlight societal categories which, being modulations of form, methodologically constitute the guiding thought in the study of different contexts and situations. ${ }^{12-13}$

Nine women participated in this study, all women met the criteria for inclusion of sexual abuse in the family context in childhood or adolescence and were over 18 years of age. Women who suffered other types of violence during childhood and those who, despite meeting the inclusion criteria, were not able to answer the research questions due to emotional disturbances, were excluded.

The approximation with the participants occurred through the extension project "Intervention Workshops with Women Victims of Domestic
Violence", in a Center for Assistance to Women in Situation of Violence in the semi-arid region of Pernambuco, during which, those meeting the inclusion criteria were invited to participate. After being duly informed, the nine participants, who agreed to participate in the research, signed two copies of the the Term of Free and Informed Consent, with the original being kept by the researcher.

The data collection took place between June and November 2014, with an open interview, whose organization and interpretation followed the Maffesolian orientation, ${ }^{12}$ with regard to the need to epistemologically investigate groupings by affinity, to give meaning to the diversity of societal phenomena identified in the researches. Thus, after the transcription of the recording of the interviews, an exhaustive reading was performed including words, repetitions, pauses, silences or overlaps, with posterior editing of the sentences in a clearer version of the one that was expressed, valuing small insignificances that integrate the daily life of each person, so often unnoticed by nursing.

Thus, the data were grouped by affinity and the conjunction was formed: the silent experience: from the hidden to the revelation of sexual abuse, in which we explore the repetition that characterizes a ritual of sexual abuse, with data organization in three categories: 1) ritualization of sexual abuse in children and adolescents in the family routine: acceptance of life through passivity; 2) camouflage to survive the experience of sexual abuse: silence, astuteness and acting/pretending; And 3) between the hidden and the revelation of sexual abuse. The research project was approved by the Research Ethics Committee of the Nursing School of the Universidade Federal da Bahia (protocol 684.203, CAAE 24565213.4.0000.5531). To safeguard and maintain anonymity, the participants were identified with fictitious names: Eva, Marta, Clara, Lara, Rosa, Alice, Júlia, Isaura and Mel.

\section{RESULTS}

The nine participants were between 18 and 53 years of age, the level of schooling ranged from incomplete elementary school to completed secondary education, they described themselves as brown (5), black (2) and white (2). Four were single, one in a consensual union, two were married, one was widowed and one was divorced. As for the monthly income, seven were unemployed and financially dependent on the family, one retired and one 
received a minimum wage. Seven had children, with one daughter resulting from the sexual abuse perpetrated by her stepfather.

As regards to age, when the sexual abuse began, the women were between four and 17 years of age, six of whom were less than ten years old. The mean time between onset and disclosure of abuse was 12 years, and the age at disclosure ranged from 11 to 53 years.

Three fathers and four stepfathers, followed by brothers and cousins, were the abusers. We identified the presence of more than one abuser in the same abusive situation: one of the participants was abused by three cousins and the other by two siblings. Regarding the type of initial contact of abusive practices, six situations occurred through caresses and small acts of gratification, and in the others (3) with genital penetration.

Regarding the disclosure, six were intentionally made to a relative or school, one occurred by being caught by relatives, one was stimulated by the Guardianship Council and the other was made at age 53 by the participant during psychological counseling. Official reporting to the department of child and adolescents protection occurred only in four situations, generating, among the protective measures, the removal of the abuser and the referral of the victim to psychological services.

The reports of the seven participants who were abused by their parents or stepfathers were contested by four mothers. Of these seven situations, the mothers of two participants separated from the abusers of their daughters and the other five continued with the companions. The following are the results grouped by categories.

\section{Ritualization of sexual abuse of children and adolescents in the family routine: acceptance of destiny through passivity}

The episodes of sexual abuse occurred without a witness, repetitively, and the power of the abusers threatened the defenseless girls with words or gestures who, by not being able to flee, remained passive, in silence and without contest.

When I was eight, my father caressed me, touched my breasts, and when I was 13 years old he began to engage in penetrative sex. It was like this: I slept in a room with three brothers, and every morning my father would leave my mother's bedroom and come to our room. I kept the sexual abuse secret until I was 17, for fear that he would kill my mother and my siblings (Marta, 19, sexually abused by her father, from 8 to 17 years of age).

Being sexually abused is a terrifying experience, in a ritual of threats and fears.

My mother studied at night and my stepfather came home from work, waited for my sister to sleep and began to abuse me. First with caresses, then he began to touch my private parts. Then he started kissing me and at the age of seven there was penetration, he ejaculated and I did not know what it was, I did not know anything. It was not every day, but there was always abuse. I didn't say it directly that I was being abused directly to my mother because I was afraid he would do something to her and my two sisters because he said that if I told anyone he would do something to them (Lara, 21, sexually abused by her stepfather, from 7 to 11 years of age).

I could not avoid being abused by my stepfather and it happened for a long time. Until a time comes and we get used to it, we do not know what to do and we let it happen (Clara, 21, sexually abused by her stepfather, from 11 to 17 years of age).

\section{Camouflages to survive the experience of sexual abuse: silence, astuteness and acting/ pretending}

The unsaid has meaning in the expression of what is not verbalized, and can occur by means of gestures or by a simple condemning look.

My father did not threaten me with words so that I wouldn't tell anyone about the abuse, but I could tell from his intimidating look, because he did not say anything, but he touched and mistreated me with touches and looks, his gaze condemned me. (Marta, 19, sexually abused by the father, from 8 to 17 years of age).

The truth about the abuse can be replaced by a shared silence on one side by an abused daughter and the other by a mother who keeps silent.

My stepfather asked me not to tell anybody, and I didn't tell anybody because I did not feel supported. First, I didn't have my mother, because she was on his side. People already knew about the abuse so did she not know? This does not get into my head at all. For me, she knew and kept quiet, pretending she did not know (Clara, 21, sexually abused by her stepfather, from 11 to 17 years of age).

In these situations the suffering is so intense that the person seems to want to hide the experience of having been sexually abused.

I never revealed the abuse I suffered from my brothers and I never want my mother to know, nobody in my family knows. This was a secret I only told you, 
my analyst and the psychologist (Isaura, 53, sexually abused by two brothers).

Besides silence, other tricks can be used to make themselves understood: metaphors, laughter or ironies, for example.

When I was about 14 years old, there was a program on TV about pedophilia, I was scared to death, but I could no longer be abused by my father, so I said: if that happened to me, I would report it; and my father looked down at me and looked at TV, and then I moved away from him (Marta, 19, sexually abused by her father, from 8 to 17 years of age).

They are pleas, distress calls for help.

I did not tell my mother directly that I was being abused by my stepfather. I happened like that, indirectly dropping hints. I would do anything for her not to leave me alone with him, but she would left me because she trusted him. One night I said, you just go to sleep after him you're going to see (Lara, 21, sexually abused by her stepfather, from 7 to 11 years of age).

It was possible to resort to other tactics, like Julia, protagonist of the sexual abuse practiced by the father, who used an excuse to leave the scene.

When I was abused by my father, I was sleeping and I woke up with that man on top of me, he had already started, then I shouted: come, dad, there's a man on top of me and he said: shut up, it's me. Then to leave I said, wait, Dad, let me get some cold water? Then you can finish, and then I got up and left [...] (Julia, 36, sexually abused by her father at age 17).

By acting/pretending the girl can mislead the abuser by hiding, pretending to sleep or staying on the street.

My day-to-day life seemed like a horror movie because I was hiding all the time inside my own home. I hid under the bed, holding my breath. The only time I had to escape was when I went to school (Eva, age 28, sexually abused by three cousins, from 4 to 18).

Acting/ pretending can also be a tactic to catch the attention of other people.

There were times when I loosened the screws of the bed, the bed rocked with me and my father, but it was no use, it seems that my mother slept like a rock and my brothers did not hear either (Marta, 19 years old, sexually abused by her father, from 8 to 17 years).

For fear of the abuser, the above participant did not spontaneously reveal the sexual abuse suffered, but used it as a tactic to get the attention of the family and school. The use of this tactic aided the disclosure of abuse as described in the next category.

\section{Between the hidden sexual abuse and the revelation of sexual abuse}

There comes a time when the secret goes beyond the barrier of fear and the truth comes out, allowing the truth about the abuse emerge, which is then spontaneously or stimulated. In many situations, the revelation was an effect of the tactics used by the victims to get people's attention.

I did not directly tell anyone that my father abused me, it was a complaint made to the Guardianship Council, I think it was a school teacher who noticed my behavior and reported it. Because when I had a talk about pedophil$i a$, I hid and became nervous, then she asked me if I was being abused and I always denied it (Marta, 19, sexually abused by her father, from 8 to 17 years old).

When the abuse was discovered, my stepfather and I were sitting and he placed my hand on his penis, my brother saw him and put him out of the house. It was also the last time (Alice, 18, sexually abused by her stepfather, from 9 to 10 years of age).

In everyday rituals, people create vents to break free from a traumatic experience. Sport was the only way I was amused and expressed myself, coming home was bad [...] it was the bad part I did not like to think about [laughs]. It made me uncomfortable, you know, like you wanted to live in the school? Like a suspicion, an insecurity, in which you would not feel comfortable in that place? (Marta, 19, sexually abused by her father, from 8 to 17 years old).

Dedication to the church, caring about other people refer to organic solidarity and shows that the participants had the strength, the willingness to live, despite experiencing sexual abuse.

I dedicated myself to the church, I went to mass, and continued to do the same missionary work. This activity helps because I see people who have even bigger problems, or people who have the same problem as me but have not found support or help. Then I try to get a little comfort through the music (Eva, 28, sexually abused by three cousins, from 4 to 18 years of age).

\section{DISCUSSION}

Each family has its own rhythm of life, in a daily life that consists of emotions, differences, secrets and silencing. Many things are spoken: others, although not expressed in words, are expressed in different ways, so that certain family experiences are quietly agreed among its members, considering that the situation is difficult to be faced, because it threatens the family balance, such as sexual abuse. 
In this research, it was possible to learn from the narratives that the daily lives of the participants consisted of an underground centrality: they hid the abuse for a considerable time because they feared that the threats of the abusers, would be extended to other members of the family.

Fearing the abuser is therefore one of the main reasons for the victims' sexual abuse to be kept secret, since the victims not only fear the next episode of abuse but also the threats to the other members of the family. As much as the victim strives to reveal the abuse, she is intimidated in order to keep it as a family secret. ${ }^{14-15}$

As a threat to family life, the abusive experiences were shared silently, especially between mother and daughter, who were mistakenly convinced that this attitude would guarantee family stability. This is why, in a large number of situations of sexual abuse, despite knowing that the perpetrator is a member of the family, many mothers opt for silence, for fear of reporting the man. ${ }^{16}$ Research describes the case of a 17-year-old girl who at the age of nine had been abused by her brother and kept the fact secret for a long time, for fear that the revelation might affect the coexistence and result in the destruction of her family. ${ }^{17}$

The fact is that in these situations there are still misconceived social constructions based on patriarchal conceptions and values that do not consider family dissolution as an alternative to the problem and intensify the difficulties of its members that find themselves caught in a difficult situation to get out of. ${ }^{18}$

We note that, regardless of the type of abuse, younger children fear the consequences of reporting and remain silent for a significant period of time. In this research, the participant who was abused by three cousins, between the ages of four and 18 years of age, kept the fact hidden for fear that the threats against her and her family would be fulfilled. This shows silence as a survival strategy that helps to forget and deal with the "intolerable and exaggerated" of the abusive experience. ${ }^{19}$

The young age of the majority of participants at the time when the abusive episodes started has also been found in other studies, which shows that younger girls are more affected by sexual abuse in the family context than adolescents and thus, are the preferred target for abusers because it is easier to maintain control over them, instructing them and threatening them not to reveal the sexual abuse. ${ }^{14}$
The large number of intentional reports of the sexual abuse in this research is in line with the study in which $87 \%$ of participants reported abuse to parents, another family member, or school, showing that spontaneous disclosure is evidence of trust and mutual commitment. ${ }^{20}$ Which helps us to understand that this form of revelation is the result of a set of factors, such as the spontaneity of the victim to report, the availability of the other person to listen, the chosen moment and place where the revelation will take place. ${ }^{21}$

Therefore, overcoming the barrier of silence and revealing the abuse constituted a different moment for each case listed and, as described, there is no uniformity in this process, therefore constituting a moment of fragility, in which any haste could jeopardize disclosure. ${ }^{21}$

It became evident that the younger the age, the greater the girl's difficulty to reveal that she is being abused. This perception was also described by authors who, when analyzing data on the process of disclosure of sexual abuse in children from two to nine years of age, noticed as the child grows older, the percentage of revelation increases. They found that only one third of the children reported the abuse earlier, while the others revealed the abuse later. ${ }^{22}$

In an attempt to resist the abuse, the girl will assume passive attitudes as forms of acceptance of life or destiny, expressed by different mechanisms of survival, as a demonstration of the dissatisfaction of the oppressed with regard to their oppressor. ${ }^{10}$

In maffesolian notions, in the silent practices the problem of survival exists, understood as the "faculty of adaptation that allows one to accommodate oneself without succumbing to them". 11:253 He also says that, from the epistemological point of view, we are used to supporting ourselves in the "accounts" of social relations, and forget that they are also supported by "the unsaid". ${ }^{11}$

Thus, without necessarily confronting abusers, the participants kept the situation secret by means of prudent tactics of resistance, ${ }^{23}$ assuming different mechanisms of survival, especially silence, accompanied by other tactics, in which, seeming to agree, did not reject the impositions.

As for astuteness, it was disguised by irony and apology, showing that as a mechanism of survival, it does not occur through stated attitudes, remaining in obscurity. Astuteness is a prevention or the cleverness of which we use when we do not wish to confront ourselves with an undesirable daily 
situation, for if it is not possible to divert or avoid the situation, the tactic is to avoid confrontation and pretend that there is agreement. ${ }^{24}$

The tactic is understood as a strategy used in threatening situations while searching for protection, therefore, in this research, we notice that the participants sought to deviate from the abusive episodes in different ways and, even if they were not able, they did not contradict their abusers.

At that time, acting/ pretending came into play, a tactic used to avoid the abuser and prevent another episode from occurring: wearing different masks, being cunning and silent, they disguised and left the scene, freeing themselves of the oppression.

Thus, they created vents to escape their executioners. As an analogy in the sense of releasing something that oppresses, a vent "oxygenates the dimension of human existence, which allows the liberation of fantasies, creativity and freedom of expression, thus saving a healthy life" ${ }^{25: 25}$

Volunteer work, religion, music and sport emerged as the main vents, since being away from home meant being free, even temporarily, from the threat of being abused once again.

Dedicating oneself to the church, caring about other people, points to the spontaneity inherent in solidarity and showing the power, the will of women to live, despite the abuse suffered, showing that the notion that mutual aid and support is not limited to mechanical actions, but involves affection and being together collectively, which refers to the current conception of solidarity. ${ }^{11,26}$

Thus, there was the desire of women to be together with family members, showing the need to live together, to help and to be helped, and to emphasize the affective aspect. This logic favors what is close, every day and concrete, linking to an ethics of aesthetics, which is what brings people together, which makes them feel together and ends up being an ethical relationship or a collective bond. ${ }^{11}$

A similar desire with relatives of women in situations of gender violence was translated into research, idealizing that, faced with experiences of violence the family needs to be a place of care and good coexistence, where oppressed women find security and peace. Moreover, they seek in faith, the vent to strengthen themselves. ${ }^{27}$

This research has limitations, considering that the information is related to the geographical context in which it is inserted, which points to the need to develop more extended studies to portray varied social realities which make possible to understand the daily life of women and girls who experience sexual abuse. Thus, in favor of the planning of solidarity care, we highlight the scarcity of studies on sexual abuse with a theoretical-methodological basis in Comprehensive and Everyday Life Sociology.

\section{CONCLUSION}

During the development of this research, we gathered elements that have helped us to understand that sexual abuse, as well as other forms of violence, keeps an underground centrality in a silence which hides what has been experienced, and in order to understand them, it is necessary to have sensitivity, the attentive look at the smallest attitudes of everyday life, present in gestures, silence, crying, ironies or behavioral changes.

Sexual abuse broke the natural rhythm of life, affecting family life: each family had its history effected by abusive experiences, so that the memories were stored in the memory of the victims, causing them suffering.

By the time they were abused, even though they were at a disadvantage compared to thr abusers, the participants developed tricks to survive, showing the latent strength that each one possessed.

As nurses, through the various spaces of care we have, we understand that it is necessary to widen our gaze in order to capture small manifestations or behaviors present in women that may be associated with experiences of sexual abuse in the family routine.

Therefore, we are committed to helping women who have been sexually abused to follow the rhythm of life, using their experiences, and being aware of the current reality, without fixing themselves in a certain phase of the past, so that they can see the importance of the present moment, freeing oneself from memories and transforming the experience of sexual abuse. The contributions of this work may help in the identification of innumerable needs arising from the experience of sexual abuse.

\section{REFERENCES}

1. Ministério da Saúde (BR), Secretaria de Atenção à Saúde. Linha de cuidado para a atenção integral à saúde de crianças, adolescentes e suas famílias em situação de violências: orientação para gestores e profissionais de saúde. Brasília (DF): MS; 2010.

2. Nudel, CR. Abuso sexual intrafamiliar: el dibujo conjunto como medio de evaluación. Lo icónico y 
lo plástico en el gráfico. Subjet Proc Cogn [Internet]. 2014 Dez [cited 2016 Dec 18]; 18(1):245-73. Available from: http:/ / dspace.uces.edu.ar:8180/xmlui/ bitstream/handle/123456789/2481/Abuso_Nudel. pdf? sequence $=1$

3. World Health Organization. Global status report on violence prevention 2014. Geneva (SW): World Health Organization; 2014 [cited 2015 Mar 19]. Available from: http://www.who.int/violence_injury_prevention/ violence/status_report/2014/report/report/en/

4. Deslandes SF, Vieira LJES, Cavalcanti LF, Silva R. Atendimento à saúde de crianças e adolescentes em situação de violência sexual, em quatro capitais brasileiras. Interface. 2016 Out-Dez; 20(59):865-77.

5. Rodrigues VP, MachadoJC,Simões AV, Mendes VMMP, Paiva MS, Diniz, NMF. The practice of family health strategy workers when caring for women in gender violence situations. Texto Contexto Enferm [Internet]. 2014 Jul-Set [cited 2016 Dec 18]; 23(3):735-46. Available from: http://www.scielo.br/scielo.php?script=sci_ arttext\&pid=S0104-07072014000300735

6. Sanchez-Meca J, Rosa-Alcázar AI, López-Soler C. The psychological treatment of sexual abuse in children and adolescents: A meta-analysis. Int J Clin Health Psychol. 2011. Jan; 11(1):67-93.

7. Lima JA, Alberto MFP. Abuso sexual intrafamiliar: as mães diante da vitimação das filhas. Psicol Soc. 2012 Mai-Ago; 14(1): 412-20.

8. Arpini DM, Siqueira AC, Savenagno SDO. Trauma psíquico e abuso sexual: o olhar de meninas em situação de vulnerabilidade. Psicol Teor Prát. 2012 Abr-Jun; 14(2):88-101.

9. Franco A, Ramírez L. Abuso sexual infantil: perspectiva clínica y dilemas ético-legales. Rev Colomb Psiquiat [Internet]. 2016 Jan [cited 2016 Dec 18]; 45(1): 51-8. Available from: http://www.elsevier.es/es-revistarevista-colombiana-psiquiatria-379-articulo-abusosexual-infantil-perspectiva-clinica-S0034745015001122

10. Maffesoli M. A dinâmica da violência. São Paulo (SP): Revista dos Tribunais; 1987.

11. Maffesoli M. O tempo das tribos: o declínio do individualismo nas sociedades de massa. $4^{\mathrm{a}}$ ed. São Paulo (SP): Forense Universitária; 2010.

12. Maffesoli M. O conhecimento comum: introdução à sociologia compreensiva. Porto Alegre(RS): Sulinas; 2010.

13. Rodríguez-Borrego MA, Nitschke RG, Prado ML, Martini JG, Guerra-Martín MD, González-Galán C. Theoretical assumptions of Maffesoli's sensitivity and problem-based learning in nursing education. Rev Latino-Am Enfermagem. 2014 Mai-Jun; 22(3):504-10.
14. Lugão KVMSF, Gonçalves GE, Gomes IM, Silva VP, Jacbson LSV, Cardoso CAA, et al. Abuso sexual crônico: estudo de uma série de casos ocorridos na infância e na adolescência. DST J Bras Doenças Sex. 2012 Jul-Set; 24(3):179-82.

15. Scortegagna AS, Villemor-Amaral AE. The use of the Rorschach method in the investigation of sexual abuse of children. Rev Paidéia. 2012 Mai-Ago; 22(52): 271-9.

16. Angel M, Prado SI, Cruz AC, Ribeiro MO. Nurses' experiences caring for child victims of domestic violence: a phenomenological analysis. Texto Contexto Enferm [Internet]. 2013 Jul-Set [cited 2016 Dec 18]; 22(3):585-92. Available from: http:/ / www.scielo.br/scielo.php?pid=S010407072013000300003\&script=sci_arttext\&tlng=en

17. Martinez-Martin N, Ruano-Maldonado S. Lo que el síntoma esconde: un caso de abuso sexual. Cuad Trab Soc [Internet]. 2013 Jan [cited 2016 Dec 18]; 26(2):30514. Available from: http://revistas.ucm.es/index. php/CUTS/article/view/42546/41367

18. Santoucy LB, Santos VA, Conceição MIG, Costa LF. Mulheres que denunciam violência sexual intrafamiliar. Rev Estud Fem [Internet]. 2014 Set [cited 2016 Dec 18]; 22(3):731-54. Available from: http://www.scielo.br/scielo.php?script=sci arttext\&pid=S0104-026X2014000300002\&lng=pt\&n $\mathrm{rm}=\mathrm{iso}>$.

19. Oliveira MD, Sei MB. Abuso sexual e as contribuições da psicologia no âmbito judiciário. Barbarói [Internet]. 2015 Jul [cited 2016 Dec 18]; 2(41):4-22. Available from: https://online.unisc.br/seer/index.php/barbaroi/ article/view/3732

20. Baía PAD, Veloso MMX, Magalhães CMC. Caracterização da revelação do abuso sexual de crianças e adolescentes: negação, retratação e fatores associados. Temas Psicol. 2013 Jun; 21(1):193-202.

21. Santos SS, Dell' Aglio DD. O processo de revelação do abuso sexual na percepção de mães. Psicol Teor Prát. 2013 Jan-Abr; 15(1):50-64.

22. Arredondo V, Saavedra C, Troncoso C, Guerra C. Develación del abuso sexual en niños y niñas atendidos en la Corporación Paicabi. Rev LatinoAm Ciênc Soc Niñez Juv [Internet]. 2016 Jan [cited 2016 Dec 18]; 14(1): 385-99. Available from: http:// revistaumanizales.cinde.org.co/index.php/RevistaLatinoamericana/article/view/2368

23. Gomes AMA, Nations MK, Luz MT. Pisada como pano de chão: experiência de violência hospitalar no nordeste brasileiro. Saúde Soc 2008 Jan-Mar; 17(1): 61-72. 
24. Decesaro MN, Ferraz CA. Resistance mechanisms of family members in face of a disease: a look based on everyday life sociology. Rev Enferm UFPE [Internet]. 2015 [cited 2015 Apr 03]; 9(4):7295-303. Available from: http://www.revista.ufpe.br/revistaenfermagem/ index.php/revista/article/download/6281/11882

25. Tholl AD, Nitschke RG. A ambiguidade de sentimentos vivenciados no quotidiano da equipe de enfermagem pediátrica. Rev Soc Bras Enferm Pediatr. 2012 Jul; 12(1):17-26.
26. Pereima RSMR, Reibnitz KS, Martini JG, Nitschke RG. Blood donation: mechanic solidarity versus organic solidarity. Rev Bras Enferm. 2010 Mar-Abr; 63(2):322-7.

27. Rodrigues VP, Machado JC, Santos WS, Santos MFS, Diniz NMF. Gender violence: representations of relatives. Texto Contexto Enferm [Internet]. 2016 [cited 2017 Feb 07]; 25(4):e2770015-10. Available from: http://www.scielo.br/pdf/tce/v25n4/0104-0707tce-25-04-2770015.pdf 